\title{
The Determination of Small Quantities of Bacteria by means of the Biuret Reaction
}

\author{
BY L. H. STICKLAND \\ Department of Experimental Pathology and Cancer Research, \\ University of Leeds
}

SUMMARY: The serum-protein determination method of Robinson \& Hogden (1940), using the biuret reaction, has been applied to the determination of small quantities of bacteria. This 'direct protein' estimation involves about threequarters of the total protein of the bacteria.

When a suspension of coliform bacteria, suitably washed and suspended in distilled water or saline, is treated with sodium hydroxide and copper sulphate, according to the method of Robinson \& Hogden (1940) for the determination of serum proteins, and the excess of copper hydroxide removed by centrifugation, a clear purple solution is obtained. The intensity of the colour is linearly proportional to the quantity of bacteria present over a wide range, and its measurement in the Spekker photoelectric absorptiometer provides a rapid and accurate means of determination. The method has proved most useful for small quantities of bacteria, as a micro-method using the $0.5 \mathrm{ml}$. cells of the absorptiometer. When enough material is available, the larger (10 ml.) cells of the absorptiometer may be used with some gain in accuracy.

Some other groups of bacteria, and yeasts, do not react in this way, but give a biuret colour which is chiefly bound to the cells. In these cases (e.g. Staphylococcus aureus; 'baker's yeast') the biuret colour may be obtained in soluble form if the mixture of bacteria and sodium hydroxide be heated in a boiling water-bath for a few minutes and then cooled, before the addition of the copper sulphate.

\section{EXPERIMENTAL}

Preparation of suspensions. The suspensions were prepared without special treatment for use in various enzyme studies. Liquid cultures were centrifuged, the bacteria suspended in distilled water and filtered through glass wool, recentrifuged and finally resuspended in distilled water. From solid media the bacteria were removed by gentle shaking with distilled water, the suspension filtered through glass wool, centrifuged and the bacteria washed once and again resuspended in distilled water.

\section{Calibration of the absorptiometer scale}

A series of volumes of a bacterial suspension containing up to $5 \mathrm{mg}$. dry weight of bacteria was measured out into small test-tubes, water added to make each sample up to $1.65 \mathrm{ml}$, and each treated with $0.3 \mathrm{ml} .20 \%(\mathrm{w} / \mathrm{v})$ $\mathrm{NaOH}$, and then $0.05 \mathrm{ml} .25 \%(\mathrm{w} / \mathrm{v}) \mathrm{CuSO}_{4} .5 \mathrm{H}_{2} \mathrm{O}$ solution. The copper hydroxide precipitate so obtained was broken up with a glass rod, and the 
tubes centrifuged at 3,500 r.p.m. for $15 \mathrm{~min}$. The supernatant solutions were decanted and their colour intensities read on the Spekker absorptiometer, using the $\mathbf{0 . 5} \mathrm{ml}$. micro-cells, and the yellow-green filter.

On the same suspensions determinations of total $\mathbf{N}$ (by micro-Kjeldahl) or dry weight or both were carried out. The Spekker readings, plotted against total $\mathbf{N}$ or dry weight, gave a straight line (Fig. 1 ). This calibration has been done with a number of strains of Bacterium coli, with reasonably concordant results (see below). A strain of Aerobacter aerogenes gave results similar to those obtained with Bact. coli (see Table 2).

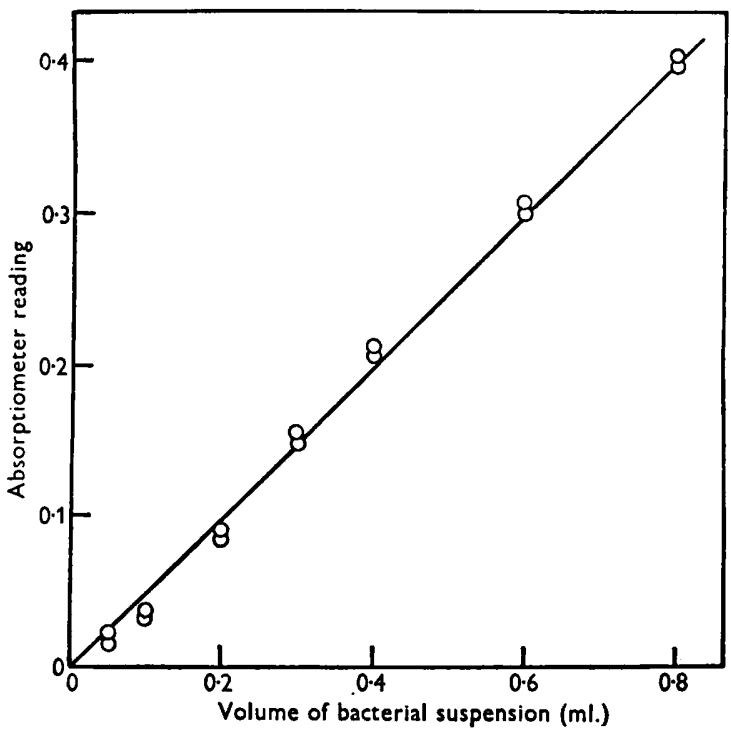

Fig. 1. The relationship between quantity of bacteria and absorptiometer reading. The suspension used contained 6.25 $\mathrm{mg}$. dry wt. $/ \mathrm{ml}$. (=3.13 mg. 'protein'/ml.).

\section{Calibration in terms of bacterial protein}

It is of interest to know what proportion of the total protein of bacteria is involved in giving this direct biuret reaction. In order to translate the colour readings into terms of absolute quantities of protein, it was necessary to measure the biuret colour given by bacterial protein, and use this as a standard. Samples of bacterial protein were obtained by treating cell suspensions with $\mathrm{NaOH}$ to a final concentration of $3 \%$, spinning out the cell residues, and precipitating the protein by the addition of $25 \%$ trichloracetic acid solution to give a final concentration of $5 \%$ of the acid. The precipitation of the opalescent colloidal solution was completed by the addition of ethanol to about $33 \%$ by volume. The protein was washed once with $5 \%$ trichloracetic acid, dissolved in water with the help of a minimal amount of $\mathrm{NaOH}$, and filtered. This solution was used for biuret colour measurements and total $\mathbf{N}$ determinations (Table 1). 
Table 1. Comparison of intensity of biuret colour obtained with rabbit-serum protein and with various samples of protein from Bact. coli

$\begin{array}{cc}\text { Protein preparation } & \begin{array}{c}\text { Absorptiometer reading } \\ \text { for } 1 \text { mg. protein }\end{array} \\ \text { Rabbit serum } & \mathbf{0 \cdot 1 5 2} \\ \text { Bact. coli (mixed strains) } & \mathbf{0 \cdot 1 6 7} \\ \text { (strain A) } & \mathbf{0 \cdot 1 5 0} \\ \text { (strain B) } & \mathbf{0 \cdot 1 5 6} \\ \text { (strain A) } & \mathbf{0 \cdot 1 6 1} \\ \text { (strain AD) } & \mathbf{0 \cdot 1 6 7} \\ \text { Average for Bact. coli } & \mathbf{0 \cdot 1 6 0}\end{array}$

Table 2. The relation of dry weight, total $N$, and protein content as determined by the biuret reaction, in suspensions of Bact. coli and $\mathbf{A}$. aerogenes in distilled water

\begin{tabular}{|c|c|c|c|c|c|c|c|c|c|}
\hline \multirow{3}{*}{$\begin{array}{l}\text { Species } \\
\text { and } \\
\text { strain } \\
\text { Bact. coli } \\
\text { B }\end{array}$} & \multicolumn{2}{|c|}{$\begin{array}{c}\text { Conditions } \\
\text { of } \\
\text { growth }\end{array}$} & $\begin{array}{c}\text { Duration } \\
\text { of growth } \\
\text { (hr.) }\end{array}$ & $\begin{array}{l}\text { Dry wt. } \\
\text { mg./ml. }\end{array}$ & $\begin{array}{l}\text { Total N } \\
\mathrm{mg} . / \mathrm{ml} \text {. }\end{array}$ & $\begin{array}{l}\text { 'Protein' } \\
\text { mg./ml. }\end{array}$ & 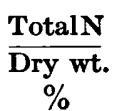 & \multirow[t]{2}{*}{$\frac{\text { 'Protein' }}{\text { Dry wt. }}$} & 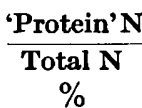 \\
\hline & & & & & & & & & \\
\hline & $\begin{array}{r}\text { Broth } \\
\mathbf{3 7 ^ { \circ }} \\
\text { Broth }\end{array}$ & & $16-20$ & $7 \cdot 7$ & 0.95 & $3 \cdot 67$ & $12 \cdot 4$ & 48 & 64 \\
\hline & $37^{\circ}$ & & $16-20$ & $8 \cdot 1$ & 1.01 & 3.91 & $12 \cdot 4$ & 49 & 64 \\
\hline $\mathbf{x}$ & Broth & $37^{\circ}$ & $16-20$ & $11 \cdot 75$ & 1.38 & 5.7 & 11.8 & 49 & 70 \\
\hline 1 & - & - & 18 & $\mathbf{3 . 4}$ & 0.41 & 1.74 & $12 \cdot 0$ & 51 & 71 \\
\hline 4 & - & - & 18 & $5 \cdot 5$ & 0.85 & $\mathbf{3} \cdot 40$ & $15 \cdot 4$ & 62 & 66 \\
\hline 14 & - & - & 20 & 5.3 & $0 \cdot 69$ & $2 \cdot 54$ & 13.0 & 48 & 61 \\
\hline AD & - & - & 20 & 5.9 & 0.77 & $2 \cdot 87$ & $13 \cdot 1$ & 49 & 62 \\
\hline 1R & - & - & 18 & - & 0.099 & 0.44 & - & - & 74 \\
\hline $\mathbf{4 R}$ & - & - & 18 & - & $0 \cdot 120$ & 0.46 & - & - & 64 \\
\hline $\mathbf{1 R}$ & Glucos & e broth & & & & & & & \\
\hline & $\begin{array}{c}\mathbf{3 7}^{\circ} \\
\text { Glucos }\end{array}$ & & 15 & - & 0.246 & 0.89 & - & - & 60 \\
\hline $\mathbf{4 R}$ & $\begin{array}{l}\text { Glucos } \\
\mathbf{3 7}^{\circ} \\
\text { Glucos }\end{array}$ & $\begin{array}{l}\text { e broth } \\
\text { e broth }\end{array}$ & 15 & - & $0 \cdot 180$ & 0.64 & - & - & 59 \\
\hline 4 & $\begin{array}{c}\mathbf{3 7}^{\circ} \\
\text { Glucos }\end{array}$ & & 15 & $2 \cdot 45$ & 0.315 & 1.22 & 12.8 & 50 & 65 \\
\hline 1 & $\begin{array}{r}37^{\circ} \\
\text { Glucos }\end{array}$ & & 15 & $2 \cdot 35$ & 0.305 & $1 \cdot 12$ & 13.0 & 48 & 61 \\
\hline $1 R$ & $\begin{array}{r}37^{\circ} \\
\text { Glucos }\end{array}$ & e broth & 15 & $7 \cdot 2$ & 0.84 & $3 \cdot 15$ & $11 \cdot 7$ & 44 & 62 \\
\hline & $37^{\circ}$ & & 15 & 4.4 & 0.62 & $2 \cdot 28$ & 14.0 & 52 & 61 \\
\hline 1 & Broth & $37^{\circ}$ & $16-20$ & $6 \cdot 6$ & 0.74 & 3.04 & 11.2 & 46 & 69 \\
\hline A. aeroge & enes & $30^{\circ}$ & 8 & 4.64, & - & $2 \cdot 25$ & - & 48 & - \\
\hline & & $30^{\circ}$ & 16 & 3.38 & - & $1 \cdot 70$ & - & 50 & - \\
\hline & & $30^{\circ}$ & 24 & $4 \cdot 25$ & - & $2 \cdot 03$ & - & 48 & - \\
\hline & lucose & $30^{\circ}$ & 16 & $2 \cdot 72$ & - & $1 \cdot 42$ & - & 52 & - \\
\hline & broth & $37^{\circ}$ & 16 & 3.44 & - & 1.73 & - & 50 & - \\
\hline & & $26^{\circ}$ & 16 & 1.06 & - & 0.59 & - & 55 & - \\
\hline & & $30^{\circ}$ & 16 & $1 \cdot 18$ & - & 0.58 & - & 50 & - \\
\hline & & $64^{\circ}$ & 16 & 1.57 & - & 0.72 & - & 46 & - \\
\hline & & & Aver & $\begin{array}{r}\text { ages; }(a) \\
(b)\end{array}$ & $\begin{array}{l}\text { ct. coli } \\
\text { aeroger }\end{array}$ & & $\begin{array}{r}12 \cdot 7 \\
-\end{array}$ & $\begin{array}{l}50 \pm 4 \\
50 \pm 2\end{array}$ & $65 \pm 4$ \\
\hline
\end{tabular}

* 'Protein' refers to 'directly estimated protein'. 'Protein $N$ ' is derived from 'Protein' by dividing the latter by $6 \cdot 0$. 
The relationship between absorptiometer reading and absolute amount of bacterial protein having been established in this way-the ratio of $0 \cdot 160 \mathrm{did}$ not differ much from that for serum protein $(0 \cdot 152)$-it was now possible to determine the value of the ratio 'protein directly estimated by the biuret reaction': 'total N'. Various suspensions of cells, from a number of strains of Bact. coli and a single strain of $\boldsymbol{A}$. aerogenes, grown under different conditions, were submitted to estimations of $(a)$ dry weight, $(b)$ total $\mathbf{N}$ by Kjeldahl, and (c) 'directly estimated protein' by the biuret reaction. In Table 2 it will be seen that variations of strain and growth conditions did not lead to very marked differences in the ratios of these quantities.

\section{Application to other micro-organisms}

When the above method was applied to suspensions of yeast the final solution obtained was almost colourless and the centrifuged deposit of cells and copper hydroxide had a purple tinge. However, if after the addition of the sodium hydroxide the mixture were heated in a boiling water-bath for periods up to $10 \mathrm{~min}$., and then cooled before the addition of the copper sulphate solution, the results in Table 3 were obtained. The 'protein' determination after some 5 min. reached a maximum, which was reasonably stable to further heating.

Table 3. The effect of heating for various times in a water-bath at $100^{\circ}$ on the intensity of the biuret colour produced by microorganisms

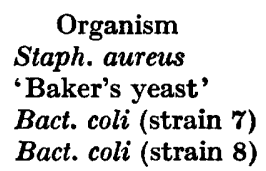

\begin{tabular}{ccccc}
\multicolumn{4}{c}{ Time of heating (min.) } \\
0 & $\begin{array}{l}\text { 1 } \\
\text { Absorptiometer reading }\end{array}$ & 10 \\
\hline 0.095 & 0.285 & 0.413 & 0.435 & 0.412 \\
0.065 & 0.491 & 0.533 & 0.545 & 0.531 \\
0.468 & & 0.481 & 0.469 & 0.458 \\
0.480 & & 0.489 & 0.490 & 0.475
\end{tabular}

Certain bacteria behaved in the same way (e.g. Staph. aureus, see Table 3) and although this matter has not been explored any further, it seems likely that the method would prove to be of general applicability, provided that the step of heating for $5 \mathrm{~min}$. at $100^{\circ}$ were included. Table 3 also illustrates the point that with coliform bacteria heating in this way brings about no significant increase in the yield of protein.

With Staph. aureus, a single determination on each of five strains gave figures for the ratio 'protein': dry weight of $46,48,46,50$, and $45 \%$ (average $47 \%$ ). A single determination on a sample of 'baker's yeast' gave a value of $71 \%$. Clearly with other micro-organisms the value of this ratio would have to be determined afresh. 


\section{DISCUSSION}

Tables 1 and 2 show that the greater part of the protein of bacteria will react with alkaline copper solution to give a biuret colour which is soluble in water and can serve as a means of measurement of the quantity of bacteria present. In various strains of Bact. coli the ratio 'directly estimated protein' $\mathbf{N}$ : total $\mathrm{N}$ is fairly constant, with an average value of $65 \%$. Just how much of the total $\mathbf{N}$ of bacteria is non-protein $\mathbf{N}$ is uncertain; Boivin \& Mesrobeanu (1934; quoted in Topley \& Wilson's Principles of Bacteriology and Immunity, 1946) say that not less than $80 \%$ of the total bacterial $\mathrm{N}$ is protein $\mathrm{N}$, but the information is scanty and unreliable. If $85 \%$ be adopted arbitrarily as a probable figure for the ratio protein $\mathbf{N}$ : total $\mathbf{N}$, then the ratio 'directly estimated protein': total protein has an average value of $76 \%$ (and it clearly could not in any case be less than $65 \%$ ). It is rather surprising to find that so large a proportion of the total protein of bacteria will react directly with copper in alkaline solution in this way, but the fact may give greater confidence in the use of the method for the determination of quantities of bacteria.

If a comparison of this method with those previously available is made, the following points may be noted. Total $\mathrm{N}$ by micro-Kjeldahl, though more sensitive and showing slightly greater accuracy, requires more care and much more time. Direct dry weight measurements, to give the same degree of accuracy, require a much greater amount of material. Turbidimetric methods, though simple, are less accurate.

The optimal quantity of bacteria for a micro-determination is about $2.5 \mathrm{mg}$. of protein ( $0.5 \mathrm{mg}$. $\mathrm{N}$ or $5 \mathrm{mg}$. dry wt.) with a probable error of about $\pm 2 \%$, and amounts down to $0.5 \mathrm{mg}$. of protein or less may be determined with confidence though with a corresponding decrease in accuracy. Under the conditions described, the quantity used for a determination must not exceed about $3 \mathrm{mg}$. of protein, as above that limit the intensity of the colour is no longer proportional to the quantity of bacteria. These estimates of accuracy apply, of course, only to the figures for 'directly estimated protein'; if they have to be converted to 'total N' or 'dry weight', slightly greater uncertainty is introduced, as can be seen from Table 2. For many purposes, however, the protein content of a culture or suspension of bacteria might be more relevant than either its dry weight or its $\mathbf{N}$ content.

The method might prove useful for comparing amounts of growth on different media or under different conditions. In this case the bacteria would have to be freed by washing from any protein components of the medium, and also from substances such as ammonium salts and amino-acids which give a blue colour with the copper reagent. Alternatively, interference from these latter substances could be eliminated by using a blue filter in the place of the yellow-green in the absorptiometer, but with loss of about one half of the sensitivity. 


\section{REFERENCES}

Borvin, A. \& Mesrobeanu, L. (1934). Contribution à l'étude de la composition chimique de la cellule bactérienne. Substance azotées et phosphorées 'acidosolubles' (techniques et premiers résultats). Arch. roum. Path. exp. Microbiol. $7,95$.

Robinson, H. W. \& Hogden, C. G. (1940). The biuret reaction in the determination of serum proteins. 2. Measurements made by a Duboscq colorimeter compared with values obtained by the Kjeldahl procedure. J. biol. Chem. 135, 727.

Topley \& Wilson's Principles of Bacteriology and Immunity (1946). 3rd ed., revised by Wilson, G. S. \& Miles, A. A. London: Ed. Arnold \& Co.

(Received 25 September 1950) 